\title{
BioLink
}

Jurnal Biologi Lingkungan, Industri, Kesehatan

Available online http://ojs.uma.ac.id/index.php/biolink

\section{THE FLAVONOID AND ALKALOID CONTENT OF CYCLOSORUS PARASITICUS (LINN.) FARWELL FERNS AT THE PLANTATION AREAS OF JEMBER REGENCY}

\author{
DwiSetyati*, HariSulistiyowati, Monica Paulina Erizcy, \& Tri Ratnasari \\ Program Study Biology, FMIPA, UniversitasJember, Indonesia \\ Submited : 30-10-2019; Accepted : 26-02-2020: Published : 10-08-2020 \\ *Corresponding author: E-mail: setyatidwi@yahoo.com
}

\begin{abstract}
Cyclosorus parasiticus(Linn.) Farwell is one potential medicinal ferns. The plant contains secondary metabolites-such as flavonoids and alkaloids. This study aims to determine the flavonoid and alkanoid of Cyclosorusparasiticus (Linn.) Farwell in three plantation areas of Jember Regency. Plant samples were collected from Mount Gumitir coffee plantations, Pine Garahan Village and rubber and cocoa plantations in Tancak in Jember. Samples of stems and leaves were dried at room temperature and then blended to obtain a powder. One gram of powder samples was macerated in $90 \mathrm{ml}$ of methanol for $3 \times 24$ hours then was concentrated with an evaporator to obtain a crude extract. The crude extract was tested qualitatively for flavonoids and alkaloids by the Willstätter and Dragendorff methods followed by quantitatively tests with Spectrophotometric. The results showed thatboth flavonoids and alkaloids were found in stem and leavesof Cyclosorus parasiticus (Linn) Farwell growing at three research locations. The flavonoids and alkaloidsin content found in leaveswas higher than those in stem organs. The leaves of Cyclosorus parasiticus (Linn) Farwell in Gumitir contain the highest flavonoids and alkaloids content-than those in Tancak.
\end{abstract}

Key Words: Alkaloids, flavonoids, content, Cyclosorus parasiticus

How to Cite:Setyati, D., Sulistiyowati, D., Erizcy, M.P., danRatnasari, T. (2020). The Flavonoid and Alkaloid Content of Cyclosorus parasiticus (Linn.) Farwell Ferns at The Plantation Areas of Jember Regency, BioLink: JurnalBiologiLingkungan, IndustridanKesehatan, Vol.7 (1): Hal.23-37 
Setyati, D., Sulistiyowati, D., Erizcy, M.P., \& Ratnasari, T.The Flavonoid and Alkaloid Content of Cyclosorusparasiticus(Linn.) Farwell Ferns at The Plantation Areas of Jember Regency

\section{INTRODUCTION}

Cyclosorus parasiticus (Linn.) Farwell is one of the thelypteridaceae fern tribe that has characteristics such as fibrous blackish brown root, green stem, hairy, brown base and scaly. In addition, bothsterile and fertile leaves have the same shape (lancet) and size. Bothleave surfaces are hairy, pinnate vein leaves. The arrangement of the leaves is alternate, Soriare superficial, round, arranged regularly cover the entire edge of the leaves (Duncan and Isaac, 1986; Cobb and Farnsworth, 2005; Nasution et al, 2018 ).

These ferns are generally grown in tropical and subtropical regions such as Indonesia, Malaysia, Asian, Queensland, Pacific to Tahiti, Hawaii, Africa, St. Helena and India as well as the northeastern and central parts of North America (Cobb and Farnsworth, 2005). According Kinho (2009), Cyclosorus parasiticus is a terrestrial fern growing in open or shade areas.

Many people get benefits from this plant species for treatment such as antimalarial (Wei et al., 2016), itchy skin and muscle bruising, excessive body fluids, anticancer (Fang et al., 2011), antiinflammatory (Tangavelou \& Viswanathan, 2017), gout and rheumatism (Singh, 2003). Utilization of ferns Cyclosorus parasiticus as drugs isallegedly due to the content of its secondary metabolites (Astuti et al., 2013).

Previous research reported that Cyclosorusparasiticus contains several secondary metabolites, among them are flavonoids and alkaloids found in the leaves (Tangavelou and Viswanathan, 2017).

The content of secondary metabolites such as flavonoids and alkaloids ferns varies depends on numerous factors such as the environment (ie temperature, humidity, $\mathrm{pH}$, location, soil), extracted plant parts, age, harvesting extraction and methods (Chikmawati et al., 2013, and Nasution et al, 2018). According to Ahmad et al. (2015) the composition of these secondary metabolites varies in plants organs. The fern leaves may contain higher secondary metabolites compared to other organs. Differences in the composition and content of secondary metabolites are influenced by the growth environment (Chikmawati et al., 2013).

The fern species of Cyclosorus parasiticus in Jember, East Java is found in three locations: coffee plantations Mount Gumitir, pine forests Garahan village, and area of Tancak waterfall. The forest in Mount Gumitir is classified as Gumitir plateau that lies at an altitude of 700-850 meters above sea level (Astuti, 2018). Pine Forest in Garahan Village classified as mid plains located at an altitude between 550 551 meters above sea level (Makhmud, 2018). On the other hand, Tancak waterfall located in rubber plantations and cocoa 
plantations Gunung Pasang Desa Suci subdistrict Panti is situated at an altitude of 300-900 meters above sea level (Baihaki, 2016). However, the flavonoid and alkaloid composition variability of the Cyclosorus parasiticus in those three locations have not been investigated yet. Therefore, it is necessary to investigate flavonoids and alkaloids compounds found in the Cyclosorus parasiticus (Linn.) Farwell fern in Mount Gumitir coffee plantations, Pine Garahan Village and TancakPlantation in Jember. These three areas have height differences that may influence the content of flavonoids and alkaloids in Cyclosorus. parasiticus.

\section{MATERIALS AND METHODS}

This research study was conducted in November 2018 until June 2019. Data sampling was carried out at three locations: coffee plantations of Mount Gumitir, pine plantation of Garahan village, and rubber and cocoa plantations of TancakinJember.

The tools and equipments used in this study were an analytical balance, petri dishes, shelves and test tube, flask, beakers, micropipette, beaker glass, glass bottles, rotary evaporator, Spectrophotometer UVVisible, blender, sieve, GPS, Termohigrometer, Lux meter, Soil tester, and Anemometer.
The materials used in this study were filter paper, tissue, distilled water, methanol, ethanol 70\%, $\mathrm{FeCl} 3, \mathrm{NaOHm}$, HCL 2N, Dragendorff reagent, Bromocresol green solvent, chloroform, $\mathrm{AlCl}$, potassium acetate, and magnesium.

\section{Research procedure}

\section{Sampling}

One kilogramCyclosorus parasiticus ferns samples were taken eachfrom three locations, namely in the area ofcoffee plantation Mount Gumitir, pine forest area in Garahan Village Silo Subdistrict, and rubber and cocoa Tancakplantations Gunung PasangDesaSuci, Panti subdistrict, Jember Regency.

\section{Preparation and Sample Extraction}

Cyclosorus parasiticus plant samples were separated between the stems and leaves. These samples then were washed with running water. The leaves and stems sampleswere cut into small pieces, and dried until a constant weight. These dried samples were mashed up by blending and sieving to obtain leaves and stems dust called simplicia. The simplicia sub sequently were put into glass bottles and stored at a temperature of 180C. Simpliciawas ready for secondary metabolites analysis.

As much as 1 gram of $C$. Parasiticus stem and leaves simplicia were soaked in 
$90 \mathrm{~mL}$ of methanol or a ratio of 1: 9 (Yudharini et al., 2016) for $3 \times 24$ hours.

Afterward these simplicia were filtered and concentrated by rotary evaporator for \pm 15 minutes. The crude extractsof both leaves and stem obtained was ready to be analyzedfor secondary metabolites contents.

Qualitative Test of Flavonoids by Wilstatter Method and Alkaloids by Dragendorff Method

Qualitative test of flavonoid was done by adding $1 \mathrm{~mL}$ of crude extract, $1 \mathrm{~mL}$ of $70 \%$ ethanol, 0.1 grams of magnesium powder, and 10 drops of concentrated $\mathrm{HCl}$. This mixed extract was shaken vigorously so that it changedcolor. Flavonoid positive test was indicated by the formation of red, yellow or orange (Mainawati et al., 2017).

Alkaloid test was conducted by taking a crude extract as much as $1 \mathrm{~mL}$ adding 2 $\mathrm{mL}$ of $2 \mathrm{~N} \mathrm{HCl}$ and then heating for 5 minutes and then filtering. The extract was added 2 drops of Dragendorffreagent. A positive result was indicated by the formation of alkaloids test precipitate of red brick (brown to orange) (Ning et al., 2016).
Quantitative Test of flavonoids and alkaloids:

Determination of the maximum wavelength (גmaks) of quercetin and berberine.

The compound used as a standard in determination of flavonoids level was quercetin, since quercetin is a flavonoid class of flavonolsthat have a keto group at atom C-4 and also the hydroxyl groups of atoms C-3 and C-5 which neighbors (Aminah et al., 2017). Determination of the maximum quercetin wavelength was done by running quercetin solvent at a wavelength range of $400 \mathrm{~nm}, 405 \mathrm{~nm}$, $410 \mathrm{~nm}, 415 \mathrm{~nm}, 420 \mathrm{~nm}, 425 \mathrm{~nm}, 430 \mathrm{~nm}$, $435 \mathrm{~nm}, 440 \mathrm{Nm}, 440 \mathrm{Nm}$ and $450 \mathrm{~nm}$ (Aminah et al., 2017).

The compound used as the standard determination of alkaloids level was berberine, since berberine is one of the alkaloids in the plant of turmeric extract (FibraureatinctoriaLour) (Utami et al., 2017). The determination of the maximum wavelength berberine was done by running berberine solvent at range of $200-400 \mathrm{~nm}$. (Salama et al., 2017).

The results indicated that the maximum wavelength of quercetin was $435 \mathrm{~nm}$, while the maximum wavelength of quercetin was $346 \mathrm{~nm}$. The maximum wavelength was used to measure the absorbance of the extract C.parasiticusfernssample. 
Making curve of standard quercetin and berberine

Standard quercetin was conducted in the following steps, weighing $10 \mathrm{mg}$ of quercetin and dissolving in $10 \mathrm{~mL}$ of methanol in order to obtain the concentration of $1000 \mathrm{ppm}$ stock solvent. One $\mathrm{mL}$ of this stock solvent was taken then was added $10 \mathrm{~mL}$ of methanol to get a concentration of $100 \mathrm{ppm}$. For standard solvent of quercetin $100 \mathrm{ppm}$, then made some concentration of $10 \mathrm{ppm}, 20 \mathrm{ppm}, 30$ ppm, 40 ppm, $50 \mathrm{ppm}$ and $60 \mathrm{ppm}$. Furthermore, from each of the standard that solvent concentrations of quercetin was added $0.5 \mathrm{~mL}$ and $1.5 \mathrm{~mL}$ of methanol, $0.1 \mathrm{~mL}$ of $10 \% \mathrm{AlCl} 3$ and $0.1 \mathrm{~mL}$ of $1 \mathrm{M}$ potassium acetate and $2.8 \mathrm{ml}$ of distilled water. Samples of standard solvent were then incubated for $30 \mathrm{~min}$ at room temperature. Absorbance was determined using UV-Vis spectrophotometry at maximum wavelength (Aminah et al., 2017).

Production of standard berberine solvent is as follows, weighed $10 \mathrm{mg}$ berberine and dissolved in $10 \mathrm{~mL}$ of methanol in order to obtain the concentration of 1000 ppm stock solvent. The $1 \mathrm{~mL}$ of stock solventwas taken and 10 $\mathrm{mL}$ of methanol was added to obtain a concentration of $100 \mathrm{ppm}$. Of berberine standard solvent $100 \mathrm{ppm}$, some concentration of 10 ppm, 20 ppm, 30 ppm,
40 ppm, 50 ppm and 60 ppmwere made. Each standardberberine solvent concentration was put into a tube test and added $5 \mathrm{~mL}$ of phosphate buffer at $\mathrm{pH} 4.7$ and $5 \mathrm{~mL}$ of BCG, then extracted with $5 \mathrm{~mL}$ chloroform (2 times) and chloroform phase was taken. The extract then was collected in the flask $10 \mathrm{ml}$ of chloroform was then added up to the mark. The extraction results were then checked at the wavelength of maximum absorbance (Salama et al, 2017).

\section{Assay of total flavonoid and alkaloid extract of Cyclosorusparasiticus (Linn.)}

\section{Farwell ferns}

Assay of total flavonoid content was done by weighing $10 \mathrm{mg}$ of crude extract C.parasiticus and dissolving it in $10 \mathrm{~mL}$ of methanol, to obtain a concentration of 1000 ppm. $0.5 \mathrm{~mL}$ of the solventwas taken then successively was added $1.5 \mathrm{~mL}$ of methanol, $0.1 \mathrm{~mL}$ of $10 \% \mathrm{AlCl} 3$ and $0.1 \mathrm{~mL}$ of $1 \mathrm{M}$ potassium acetate and $2.8 \mathrm{~mL}$ of distilled water. The sample solventwas incubated for $30 \mathrm{~min}$ at room temperature. Absorbance was determined using UV-Vis spectrophotometry at maximum wavelength. Samples were made in three replications for each analysis and then absorbance measurement was averaged value (Aminah et al., 2017).

Assay of total alkaloid content was done by extractingviscouslythe fern 
sample of $50 \mathrm{mg}$ dissolved in $3 \mathrm{~mL}$ of $\mathrm{HCl} 2$ $\mathrm{N}$. The solventwas put into a tube test andwasadded $5 \mathrm{~mL}$ of phosphate buffer at pH 4.7 and $5 \mathrm{~mL}$ of BCG, then was extracted with $5 \mathrm{~mL}$ chloroform (2 times) and chloroform phase was taken. The extraction was collected in $10 \mathrm{~mL}$ flask, andadded again chloroform to the mark(Salama et al, 2017). The solventwas then inspected its absorbance at a wavelength of $346 \mathrm{~nm}$. Samples were made in three replications for each analysis and the result of absorbance measurement was calculated its average value.

Absorbance values were formulated into the regression equation of standard solvent of quercetin and berberine in order to obtain lower levels of total flavonoids and alkaloids as indicated by the percent total flavonoids and total alkaloids.

\section{Abiotic Factors Measurement}

Measurement of abiotic factors on the sampling locations include altitude, light intensity, humidity, and pH.Each measurement abiotic factor was repeatedfor three timesandanalyzed for the average. Determination of the altitude and position of the place was done by using the Global Positioning System (GPS). The light intensity was done by using a lux meter while the measurement of temperature and humidity was done by using hermohygrometer. Measurement of
$\mathrm{pH}$ and soil moisture measurements were by using soil tester.

\section{Data analysis}

Research data in the form of quantitative and qualitative data are compiled in table form. The qualitative data were the test results of secondary metabolites, flavonoids and alkaloids. Quantitative data of thepercent content of secondary metabolites, flavonoids and alkaloids and average data measurement results of abiotic factors were calculated. Data from the test observations of secondary metabolites were analyzed descriptively and were associated with abiotic environmental factors where the Cyclosorusparasiticus (Linn.) Farwell fern grows.

RESULTS AND DISCUSSION

Qualitative test of flavonoid extract ferns Cyclosorusparasiticus (Linn.)

\section{Farwell}

Qualitative test of secondary metabolites was done to ensure their flavonoid and alkaloid contained in the extract fern Cyclosorusparasiticus(Linn) Farwell. The test results of qualitative flavonoid and alkaloid extract this fern species can be seen in Table 1 . The red or orange colors formed indicated that the leaves and stems of ferns Cyclosorusparasiticuspositivelycontained 
flavonoids. As supported by Mainawati et that the leaves and stems of ferns $C$. al. (2017) said that the plant extract parasiticus positivelycontained alkaloids. containing flavonoids positive when it The plant extract positively contains shown the formation of red, yellow or alkaloids after being given reagent orange colorsafter adding magnesium Dragendorffthat was indicated by the chloride reagent indicated. The red formation of deposits sorrel (brown to colorwas indicatedthe reduction of the orange) (Ning et.al., 2016). The formation flavonoid result of concentrated of brick red precipitate as nitrogen formed hydrochloric acid and magnesium salts a coordinate covalent bond with $\mathrm{K}+$ metal formed flavilium (Ahmad, 1986).

Qualitative test alkaloids in leaves ions. These deposits are potassiumalkaloid (Marliana et al., 2005).

and stems of ferns Cyclosorusparasiticus indicated red precipitate. It was proved

Table 1. Results of the qualitative test flavonoid and alkaloid extract of ferns Cyclosorusparasiticus (Linn.) Farwell

\begin{tabular}{|c|c|c|c|c|c|}
\hline \multirow{2}{*}{ part Plant } & \multirow{2}{*}{ locations } & \multicolumn{2}{|c|}{ flavonoids } & \multicolumn{2}{|l|}{ Alkaloids } \\
\hline & & Color & info & Color & Info \\
\hline \multirow{3}{*}{ Leaf } & Tancak & yellowish orange & + & Brick red precipitate & + \\
\hline & Garahan & Red & + & Brick red precipitate & + \\
\hline & Gumitir & dark red & + & Brick red precipitate & + \\
\hline \multirow{3}{*}{ rod } & Tancak & Orange & + & Brick red precipitate & + \\
\hline & Garahan & Red & + & Brick red precipitate & + \\
\hline & Gumitir & Orange & + & Brick red precipitate & + \\
\hline
\end{tabular}

Note :+: Positive containflavonoids / alkaloids

- :Negative contain flavonoids / alkaloids

Determination of a standard curve of quercetin and berberine

The analysisof maximum wavelength absorption indicated that the maximum wavelength standards of quercetinwas at a wavelength of $435 \mathrm{~nm}$. It is consistent with researchstudy done by Ahmad et al. (2015) has shown the maximum wavelength is 435 $\mathrm{nm}$ quercetin. While the results of measurements of the absorption maximum wavelength of berberineindicated that the wavelength maximum standards beberinwas $346 \mathrm{~nm}$ as stated byUtami et al.
(2017) that the maximum wavelength is $346 \mathrm{~nm}$ quercetin.

Absorbance measurement of quercetin standard solvent obtained was used to get a calibration curve of standard solvent of quercetin such as concentration curve graph versus absorbance. A calibration curve with a regression equation for absorbance quercetin is $\mathrm{y}=0,0047 \mathrm{x}+$ 0.0094 (figure 1). 
Setyati, D., Sulistiyowati, D., Erizcy, M.P., \& Ratnasari, T.The Flavonoid and Alkaloid Content of Cyclosorusparasiticus(Linn.) Farwell Ferns at The Plantation Areas of Jember Regency

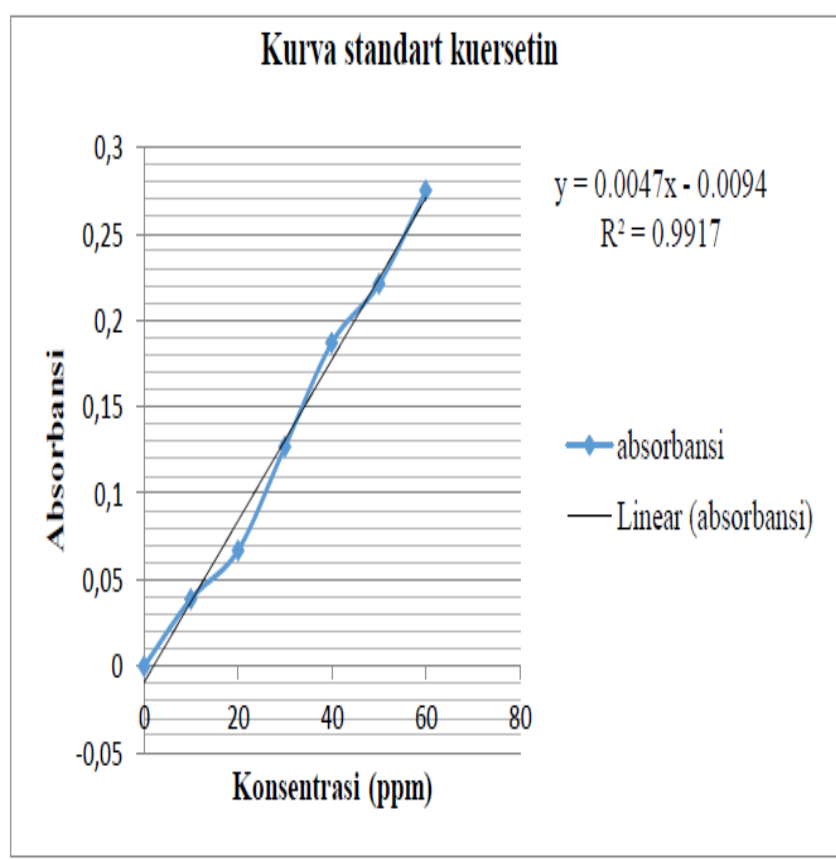

Figure 1. Standard curve of quercetin at a wavelength of $435 \mathrm{~nm}$ maximum

The results of the calibration curve of of the calibration curve of standard solvent standard solvent of the compound of the berberine compound was also quercetinwasobtained linear relationship obtained a linear relationship between the between the absorbance with absorbance with concentration that was concentration. It was indicated by the value indicated by the value of the correlation of the correlation coefficient $(r)$ of 0.9917 coefficient $(r)$ of 0.9937 honing berberine 1 . quercetinis close to 1 . (Figure 2).

As for berberine regression equation $y=0,0043 x+0.0099$ (Figure 2). The results

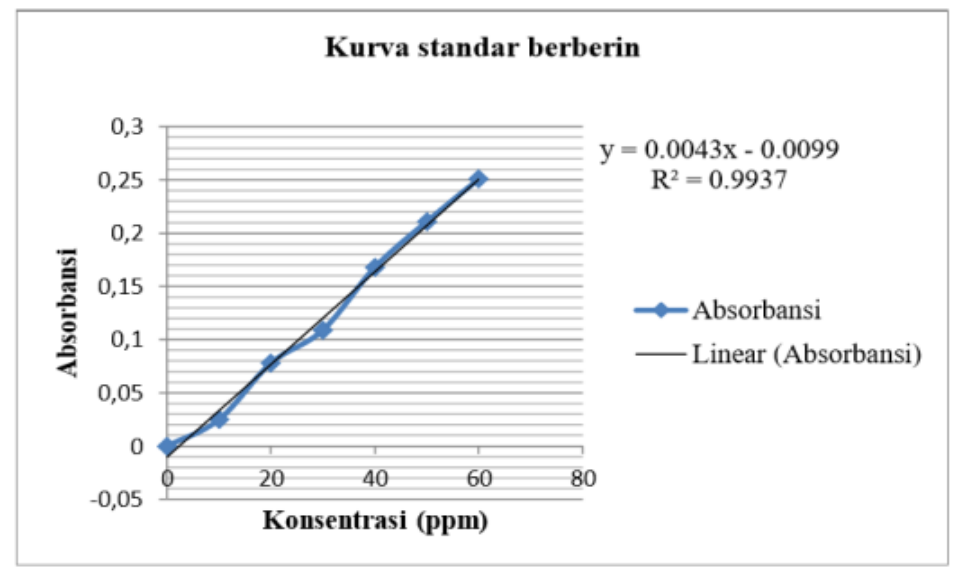

Figure 2. Standard curves of berberine at a wavelength of $346 \mathrm{~nm}$ maximum 
Quantitative Test of alkaloid and distribution of secondary metabolites in flavonoids extract of plant organs (Ahmad et al., 2015). In Cyclosorusparasiticus (Linn.) Farwell addition, the secondary metabolites, ferns

The average level of flavonoids and flavonoids and alkaloids in certain organs were affected by these secondary alkaloids leaves $C$. parasiticuswas higher metabolites plant physiology. than those in stems of all areas (table 2). The high average level of flavonoids and alkaloids in the leaves indicates the uneven

Table 2 Average levels of flavonoids methanol extract of leaves and stems fern Cyclosorusparasiticus (Linn) Farwell at three different locations

\begin{tabular}{cccc}
\hline part of plant & locations & $\begin{array}{c}\text { Average levels of } \\
\text { flavonoids Total (\%) }\end{array}$ & $\begin{array}{c}\text { Average levels of } \\
\text { alkaloids Total (\%) }\end{array}$ \\
\hline \multirow{3}{*}{ Leaf } & Tancak & .3241 & .0728 \\
\cline { 2 - 4 } & Garahan & .4462 & .1102 \\
\cline { 2 - 4 } & Gumitir & .5732 & .1662 \\
\hline \multirow{2}{*}{ Stem } & Tancak & .0306 & .0263 \\
\cline { 2 - 4 } & Garahan & .1370 & .0318 \\
\cline { 2 - 4 } & Gumitir & .5838 & .1413 \\
\hline
\end{tabular}

Cyclosorusparasiticusleaf is part of the plant that is susceptible to insect attack so that the accumulation of flavonoids and alkaloids was higher in the leaves than in the stems. The high level of flavonoids and alkaloids in the leaves intended for defense for the plants. It is supported by Gunawan et al. (2016) who said that the function of flavonoids for the plant defense against pests, microbes, and viruses, as well as protection against UV radiation. Secondary metabolite alkaloid served as toxins to protect plants from herbivores (pests and diseases), and as alkaline minerals to maintain ion balance.

This study was conducted in three plantations in Jember that had different heights. Based on Table 3, Gumitir had the highest altitude among Tancak and Garahan. 
Table 3. The average measurement of abiotic factors in three sampling sites of ferns Cyclosorus parasiticus (Linn) Farwell.

\begin{tabular}{cccc}
\hline \multirow{2}{*}{ Abiotic factors } & \multicolumn{3}{c}{ locations } \\
\cline { 2 - 4 } & Gumitir & Garahan & Tancak \\
\hline Altitude (masl) & 707 & 538.46 & 416.33 \\
\hline temperature $(\stackrel{\circ}{\mathrm{o}})$ & 29.51 & 30.25 & 28.54 \\
\hline Air humidity $(\% \mathrm{rh})$ & 66.02 & 64.34 & 77.16 \\
\hline soil pH & 5.75 & 5.48 & 4.28 \\
\hline Soil moisture (\%) & 41.55 & 50.44 & 75.55 \\
\hline The light intensity (lux) & 155.55 & 211.11 & 222.22 \\
\hline
\end{tabular}

Nuryanto et al. (2014) states that factors such as $\mathrm{pH}$ affects the formation of altitude divided into lowland (0-200 masl), both secondary metabolites. The Gumitir plains (200-600 masl) and highlands $>600$ soil $\mathrm{pH}$ was 5.75 . The soil $\mathrm{pH}$ is optimum for masl. Based on this statement, Gumitirwas included in the class of plateau for the height is 707 meters above sea level, while Garahan and Tancak included in class of mid plains at a height of 538.66 meters above sea level and 416.33 meters above sea level. Altitude somewhere related to abiotic factors such as soil acidity $(\mathrm{pH})$, light intensity, temperature, humidity, soil moisture and others. Soil pH in Gumitir (5.75) was higher than Garahan (5.48) and Tancak (4.28). $\mathrm{pH}$ tends to increase with altitude in line with increased soil organic content. Supriya et al. (2016) said that the $\mathrm{pH}$ is positively correlated with altitude.

The highest of flavonoids and alkaloids leaves was found in Gumitir. The high content of flavonoids and alkaloids in the leaves in Gumitirwassupported by the growth C.parasiticus environmental factors such as $\mathrm{pH}$, light intensity, soil moisture and others. Generally, environmental average growth of plants that is from 5.6 to 6.0 (Supriya et al., 2016). The pH of the soil is important for the plant because the soil solvent contains nutrients like $\mathrm{N}, \mathrm{K}, \mathrm{P}$ and others that the plants urgently need a certain amount to grow, thrive and survive against pest attack.

At the optimal $\mathrm{pH}$ conditions, the macro nutrients (N, P, K, Mg, Ca and S) were dissolved in the soil solvent and in availableform sothat its presence was high and absorbed easilyby plants (Jovita, 2018). Macronutrient $\mathrm{N}$ is one of the important nutrients for plants. Since a plant fulfills the need for nitrogen then its growth will be better because besides to help in the process of photosynthesis it is also to affect the result of flavonoid synthesis (Aristyanti, 2014; Pratiwi, 2017). Based on Salim et al. (2016), macro soil nutrients such as nitrogen $(\mathrm{N})$, potassium $(\mathrm{K})$, organic matter (BO) and carbon (C) 
have a linear relationship with the organic formation of secondary metabolites. By increasing availability of the macro nutrients in the soil, the establishment of flavonoids and alkaloids will also increase.

The existence of nitrogen are also able to increase the number of total chlorophyll, because nitrogen is an essential component of constituent porphyrin ring of chlorophyll which is a basic framework. It is supported by Jovita's statement (2018) that the benefits of nitrogen play a role in the formation of chlorophyll, amino acids, lipids, enzymes, and other compounds. The growth of plant with sufficient nitrogen showed an increased expression of the flavonoid biosynthetic genes (Coronado et al., 1995).

The optimal $\mathrm{pH}$ condition also affected the high content of alkaloids C..ParasiticusinGumitir. Alkaloids were secondary metabolites compounds containing nitrogen derived from the amino acid biosynthesis. The statement was supported by Wink (2008) that the alkaloids are secondary metabolites, the most that have a nitrogen atom. Therefore, increasing the formation of amino acids will affect the increased alkaloid. It is why the alkaloid content in Gumitirwas higher than Tancak.

Another factor supporting high flavonoid and alkaloid in Gumitir was light intensity. Light intensity in Gumitirwas
155.55 lux (Table 3). The light intensity is suitable to Cyclosorus parasiticus. growthBased on Mukti et al. (2016) who states that the appropriate intensity of light with the growth of ferns that is in the range of 128.3 lux - 3000 lux. The appropriate light intensity will support the optimal process of photosynthesis of a plant. The results of photosynthesis such carbohydrates will go through glycolysis to form phosphoenolpyruvate and pyruvate. Flavonoids are secondary metabolites formed from phosphoenolpyruvate and pyruvate from glycolysis stages in the process of respiration of plants. Phosphoenolpyruvate will be formed into phenolic compounds by the shikimic acid pathway while pyruvate by the malonic acid pathway (Taiz and Zieger, 2002), Flavonoids are secondary metabolites that are included in a large group of phenolic compounds (Vickery and Vickery, 1981 in Ekawati, 2018). Thus the optimal photosynthesis will indirectly increase the secondary metabolites of flavonoids. While alkaloids formed from the results of photosynthesis were carbohydrates which undergo glycolysis into acetyl CoA. Acetyl CoA through the tricarboxylic acid cycle will form amino acid that is a precursor aliphatic alkaloid formation. Alkaloids can also be generated from the aromatic amino acid produced from phosphoenolpyruvate through the shikimic acid pathway (Taiz 
Setyati, D., Sulistiyowati, D., Erizcy, M.P., \& Ratnasari, T.The Flavonoid and Alkaloid Content of Cyclosorusparasiticus(Linn.) Farwell Ferns at The Plantation Areas of Jember Regency

and Zeiger, 2002 in Setyorini and Eriyanto, 2016).

The low intensity of light in Gumitir allegedly also affected the increasing of auxin hormone. Based onRahayu et al. (2003) environmental conditions with low intensity will increase the concentration of auxin in plants. In flavonoid synthesis, auxinhasfunction to improve the action of the enzyme phenylalanine ammonia lyase (PAL), which produces cinnamic (via the shikimic acid pathway) of phenylalanine. Thus, if the content of auxin increases, the formation of flavonoids also increases.

The lowest level of flavonoids and alkaloids of leaves was found in Tancak. The low levels of flavonoids and alkaloids in these locations can not be separated from the environment in which the growth factor Cyclosorus parasiticus.Tancak had Low pH (4.28) that is classified as sour. The $\mathrm{pH}$ value of Tancakwas lower than that ofGumitir and Garahan. Tancak pH was not optimal for plant growth. The optimal $\mathrm{pH}$ for growth is 5.6 to 6.0 (Supriya et al., 2016). The condition of soil $\mathrm{pH}$ that is relatively acidic can affect the availability of nutrients that can be absorbed by plants. At acidicpH the plant was poisoning $\mathrm{Al}$ and Fe because the solubility of the two metals were high.Rosmarkam and Yuwono (2002) states that the $\mathrm{pH}$ affects the availability of nutrients, at the acid $\mathrm{pH}$, the solubility of some nutrients decreased, but the solubility of $\mathrm{Al}$ and $\mathrm{Fe}$ were high consequently the plant growth was stunted. The plant growth was inhibited among them are cause of $\mathrm{Al}$ and Fe toxicity, reduced chlorophyll biosynthesis, amino acids and proteins (enzymes).

The reduction of chlorophyll content caused the photosynthetic process inhibition. Inhibited photosynthesis resulted in impaired respiration consequently the formation of flavonoids decreases. Inhibition of respiration process causedphosphoenolpyruvate and pyruvate decrease. Both of these compounds will be formed into a phenolic compound through the shikimic acid pathway while pyruvate through malonic acid (Lincoln and Zieger, 2002), Based on Aristyanti's research (2014) which states that the flavonoids in the tabatbarito leaves (Ficusdeltoidea Jack) were less in locations with low soil pH. It is due to the land and waters that have lower pH levels in general are often encountered in conditions of nutrient deficiency, followed by a low level of productivity as well. Similarly to alkaloid biosynthesis was inhibited at low pH. Alkaloid is a nitrogencontaining secondary metabolites of amino acid biosynthesis. Nitrogen is an important organic compounds such constituent amino acids, proteins and nucleic acids (Goh and Hardter, 2010). Absorption N by plants was reduced so that the amino acid biosynthesis process reduced and 
influenced the reduction in alkaloid produced.

The low content of flavonoids in Tancakwas caused by the effect of $\mathrm{pH}$ and also the light intensity . The light intensity in Tancak is 222.22 lux. The light intensity was actually suitable for the growth C.parasiticus. The appropriate light intensity for the growth of ferns that is the range of 128.3 lux - 3000 lux (Mukti et al., 2016). The appropriate light intensity make the photosynthesis process go well. The light intensity in Tancakwas higher than that in Gumitir but still classified in the low light intensity. The higher light intensity in Tancak than in Gumitirlikely affect the lower the auxin hormone in Tancak location. The low auxin hormone also affected the flavonoid. It is supported by Rahayu et al.(2003) statement that whenauxin is reduced, flavonoid formation is also reduced.

\section{CONCLUSION}

Stems and leaves of Cyclosorus parasiticus (Linn) Farwell ferns in Gumitir, Garahan and Tancak contains secondary metabolite compounds contain flavonoids and alkaloids. The content of flavonoids and alkaloids in leaves was higher than that of in stems. Leaves Cyclosorus parasiticus (Linn) Farwell in Gumitir containe dhigher flavonoids and alkaloids compared to that in Garahan and Tancak. The highest flavonoid and alkaloid was found in the leaves Cyclosoru sparasiticus in Gumitir is $0.5732 \%$ and $0.1662 \%$, while the lowest content $(0.0306 \%$ and $0.0263 \%)$ of flavonoids and alkaloids in the stem located in Tancak.

\section{ACKNOWLEDGMENTS}

Thanks to LP2M Jember University, which has funded this research through Keris "Symplast" and all those who assist in completing this research.

\section{REFERENCE}

Ahmad, A. R., Juwita, Siti A. D. R., Abdul M. (2015). Penetapan Kadar Fenolikdan Flavonoid Total Ekstrak Metanol Buah dan Daun Patikala (Etlingera elatior (Jack) R.M.SM). Pharm Sci Res, 2(1):1-10.

Aminah, Tomayahu, N., dan Abidin, Z. (2017). Penetapan Kadar Flavonoid Total ekstrak Metanol Kulit Buah Alpukat (Persea americana Mill.) Dengan Metode Spektrofotometer Uv-Vis. Jurnal Fitofarmaka Indonesia, 4(2):226-230.

Aristyanti, D. (2014). Pengaruh Kadar Kimia Tanah Terhadap Kandungan Flavonoid DaunTabat Barito (Ficus deltoidea Jack.). Skripsi. Institut Pertanian Bogor: Bogor.

Astuti, J., Rudiyansyah, danGusrizal. (2013). Uji Fitokimia dan Aktivitas Antioksi dan Tumbuhan Paku Uban (Nephrolepis biserrata (Sw) Schhott). Jurnal Kedokteran Kesehatan 2(2): 86-92.

Astuti, R.D. (2018). Jenis-Jenis Tumbuhan Paku (Pteridophyta) BerpotensiObat Di Kawasan Gunung Gumitir Kabupaten Jember. Skripsi. Universitas Jember. Jember.

Baihaki. (2016). Air Terjun Tancak Jember Wisata Alam Tersembunyi di Jawa Timur. http://www.reresepan.com/airteriuntancak -jember-wisata-alam-tersembunyi-di-jawatimur/[Diaksespada 1 November 2018].

Chikmawati, T., Puspita, D. S., dan Miftahudin. (2013). Pertumbuhan dan analisis kualitatif tanin, saponin dan flavonoid dari Selaginella 
Setyati, D., Sulistiyowati, D., Erizcy, M.P., \& Ratnasari, T.The Flavonoid and Alkaloid Content of Cyclosorusparasiticus(Linn.) Farwell Ferns at The Plantation Areas of Jember Regency

plana, S. willdenovii and S. mayeri pada tiga naungan berbeda. Jurnal Bioslogos, 3(1):1-9

Cobb, B. and E. Farnsworth. (2005). A Field Guide to Fern and Their Related Families. Houghton Mifflin Company. Boston. New York.

Coronado, C., Zuanazzi, J., Sallaud, C., Quirion, J.C., Esnault, R., Husson, H.P., Kondorosi, A., Ratet, P. (1995). Alfalfa Root Flavonoid Production is Nitrogen Regulated. Plant Physiol, 108(2):533-542.

Duncan, B.D and G. Isaac. (1986).Fern and Allied Plants of Victoria, Tasmania and South Australia. Melbourne University Press in Association with Monash University.

Ekawati, R. (2018).Produksi Pucuk dan Kandungan Flavonoid Tanaman Kolesom pada Cekaman Naungan. J.Hort. Indonesia 9(3):216-223.

Fang, W., J. Ruan, Y. Cai, A. Wei, D.Zhou and W.Zang. (2011). Flavonoid From The Aerial Parts Of Microthelypteris torressiana. Natural Product Research. 215(1):36-39

Goh, J.K and R. Hardter. (2010). General Oil Palm Nutrition. International Potash Institute Kassel, Germany.

Gunawan, Tatik C., Sobir dan Sulistijorini. (2016). Review: Fitokimia genus Baccaurea spp. Bioeksperimen, 2(2).96-110.

Jovita, D. (2018). Analisis Unsur Makro (K, Ca, Mg) Mikro (Fe, Zn, Cu) Pada Lahan Pertanian Dengan Metode Inductively Coupled Plasma Optical Emission Spectrofotometry (ICPOES). Skripsi. Bandar Lampung :Universitas Bandar Lampung.

Kinho, J. (2009). Mengenal Beberapa Jenis Tumbuhan Paku Di Kawasan Hutan Payahe Taman Nasional Aketejawe Lolonata Maluku Utara. Manado: Balai Penelitian Kehutanan Manado. (buku)

Mainawati, D., M.B. Etidan M. Jismi. (2017). Uji Kandungan Metabolit Sekunder Tumbuhan Obat Yang terdapat Di Kecamatan Rambah Samo Kabupaten Rokan Hulu. Jurnal Mahasiswa Prodi Biologi UPP. 1-6.

Makhmud, M. (2018).InventarisasiTumbuhanPaku (Pteridophyta) BerpotensiObat Di Hutan Pinus Desa Garahan Kecamatan Silo Kabupaten Jember. Skripsi. Jember: Universitas Jember.

Mukti, L., P.D. Sudarson dan Sulistyono. (2016). Keanekaragaman Jenis Tumbuhan Obat dan Pemanfaatannya di Hutan Turgo,
Purwobinangun, Pakem, Sleman, Yogyakarta. JurnalBiologi 5(5):9-19.

Nasution, J., Fauziah, I., \& Susilo, F. (2018). Inventarisasi Selaginellaceae di Hutan Lindung Aek Nauli Parapat Sumatera Utara. Biogenesis: Jurnal Ilmiah Biologi, 5(2), 78-82.

Nasution, J., Nasution, J., \& Kardhinata, E. H. (2018). Inventarisasi Tumbuhan Paku Di Kampus I Universitas medan area. Klorofil: Jurnal Ilmu Biologi Dan Terapan, 1(2). 105110.

Nuryanto, B., Priyatmojo A., danHadisutrisno B. (2014). Pengaruh Tinggi Tempat dan Tipe Tanaman Padi terhadap Keparahan Penyakit Hawar Pelepah. Jurnal Penelitian Pertanian Tanaman Pangan, 33(1).1-8.

Pratiwi, A. (2017). Peningkatan pertumbuhan dan kadar flavonoid total tanaman bayam merah (Amaranthus gangeticus L.) dengan pemberian pupuk nitrogen. Pharmaciana, 7(1).78-94.

Rahayu, B. Solichatundan A. Endang. (2003). Pengaruh Asam 2,4-Diklorofenoksi asetat (2,4-D) Terhadap Pembentukan dan Pertumbuhan Kalus serta Kandungan Flavonoid Kultur Kalus Acalyphaindica L. Jurnal Biofarmasi 1(1):1-6.

Rosmarkam, A dan N. W. Yuwono.(2002). Ilmu Kesuburan Tanah. Yogyakarta: Kanisius.

Salim, M., Yahya, H. Sitorus, T. Ni'mahdan Marini. (2016). Hubungan Kandungan Hara Tanah dengan Produksi Senyawa Metabolit Sekunder pada Tanaman Duku (Lansium domesticum Corr var Duku) dan Potensinya Sebagai Larvasida. Jurnal Vektor Penyakit. Vol.10(1):11-18.

Setyorini, S. D., danEriyanto Y. (2016). Peningkatan Kandungan Metabolit Sekunder Tanaman Aneka Kacang sebagai Respon Cekaman Biotik. Iptek Tanaman Pangan Vol. 11 (2) :167-174

Singh, H. B. (2003). Economically Viable Pteridophytes of India. In: Chandra $S$, Srivastava, M, eds. Pteridology in the New Millennium. Kluwer Academic Publishers, Netherlands.

Taiz, L. and E. Zieger. (2002). Plant Physiology. $3^{\text {rd }}$ Ed. Sinauer Associates, Sunderland, Tyne and Wear, England.

Tangavelou, A. C., danViswanathan, M.B. (2017). Anti-inflammatory Activity of the Epidermal Glandular Extract of Cyclosorus parasiticusin 
Experimental Animals. Journal of Biologically Active Products from Nature Vol.7(3):245-250

Utami, R., F. Armon, P.S. Indah dan F. Mustika. (2017). Penetapan Kadar Berberin dari Ekstrak Etanol Akar dan Batang Sekunyit (Fibra ureatinctorial Lour) dengan Metode Kromatografi Cair Kinerja Tinggi (KCKT). Jurnal Sains Farmasidan Klinis. Vol. 03.No.02. 115-119.

Wei. H., J. Ruan., dan X. Zhang. (2016). CoumarinChalcone Hybrids: Promising Agents with Diverse Pharmacological Properties. Royal Society Of Chemistry. 1(3):1-16.
Wink, M. (2008). Ecological Roles of Alkaloids.Wink, M. (Eds.).Modern Alkaloids, Sructure, Isolation Synthesis and Biology. Wiley, Jerman: Wiley-VCH Verlag GmbH \& Co. KgaA Yudharini, G.A.Kd.F., A.A.P.A. Suryawan dan N.M. Wartini. (2016). Pengaruh Perbandingan Bahan Dengan Pelarut Dan Lama Ekstraksi Terhadap Rendemen Dan Karakteristik Ekstrak Pewarna Dari Buah Pandan (Pandanus tectorius). J. Rekayasa Dan Manajemen Agroindustri. 4(3): 36-46. 
Setyati, D., Sulistiyowati, D., Erizcy, M.P., \& Ratnasari, T.The Flavonoid and Alkaloid Content of Cyclosorusparasiticus(Linn.) Farwell Ferns at The Plantation Areas of Jember Regency 